\title{
After A Year of Follow Up Non-Cirrhotic Portal Hypertension Patient with Partial Spleen Embolization (PSE) Management
}

\author{
Akhmadu Muradi*, Chyntia Olivia Maurine Jasirwan**, Raden Suhartono*, \\ Patrianef Darwis*, Dedy Pratama*, Teguh Dwi Nugroho*, Karina Zulkarnain* \\ *Division of Vascular and Endovascular Surgery,", Department of Surgery, Faculty of Medicine \\ Universitas Indonesia/Dr. Cipto Mangunkusumo General National Hospital, Jakarta \\ ${ }^{* *}$ Division of Hepatobiliary, Department of Internal Medicine, Faculty of Medicine \\ Universitas Indonesia/Dr. Cipto Mangunkusumo General National Hospital, Jakarta
}

Corresponding author:

Akhmadu Muradi. Division of Vascular and Endovascular Surgery, Department of Surgery, Dr. Cipto Mangunkusumo General National Hospital. Jl. Diponegoro No. 71 Jakarta Indonesia. Phone: +62-21-31936030 facsimile:+62-21-3100050.E-mail: akhmadumuradi@gmail.com.

\begin{abstract}
Non-cirrhotic portal hypertension (NCPH) is a heterogeneous group of liver disorders leading to portal hypertension. Porta hypertension complications have been traditionally managed with serial endoscopic variceal ligation (EVL) or invasive open surgical procedures such as orthotopic liver transplantation (OLT) or portosystemic shunting or splenectomy. There are several risks associated with splenectomies, such as hemorrhagic complications or intraoperative blood loss. Partial Spleen Embolization (PSE) imay overcome the limitations of splenectomy and provide patients with an alternative treatment. An eighteen-year-old male has had splenomegaly since six years prior and has recurring hematemesis and melena. After performing abdominal computed tomography, laboratory studies, and several endoscopies, the results indicated secondary hypersplenism due to NCPH. The patient had 13 endoscopies and 2 EVL in 5 years. Despite adequate treatment, the patients developed recurrent variceal bleeding and no improvement in blood function. The patient underwent PSE at Integrated Cardiovascular Center in Cipto Mangunkusumo General Hospital, Jakarta, Indonesia. It was performed through the femoral access with a PVA (polyvinyl alcohol) embolus. The procedure went successful, and there was no major complication with the patient. Twenty days after the patient had an abdominal CT scan, it showed no abscess, and the spleen volume was reduced by $20 \%$. Long-term results over a year after the procedure are presented. PSE is a safe, effective, semi-invasive alternative to splenectomy in non-cirrhotic portal hypertension because it preserves functional spleen mass and avoids postprocedure accelerated liver disease or encephalopathy.
\end{abstract}

Keywords: portal hypertension, spleen embolization, variceal bleeding

\section{ABSTRAK}

Hipertensi portal non-sirosis (HPNS) adalah kelompok gangguan hati heterogen yang mengarah ke hipertensi portal. Komplikasi hipertensi porta secara tradisional dikelola dengan serial endoscopic variceal ligation (EVL) atau dengan prosedur bedah terbuka invasif seperti orthotopic liver transplantation (OLT) atau portosystemic 
shunting, splenektomi. Ada beberapa risiko yang terkait dengan splenektomi, seperti komplikasi hemoragik. atau kehilangan darah intraoperatif. Partial spleen embolization (PSE) dapat mengatasi keterbatasan splenektomi dan memberikan pasien alternatif terapi. Seorang laki-laki berusia delapan belas tahun menderita splenomegali sejak enam tahun yang lalu, dan mengalami hematemesis dan melena yang berulang. Setelah melakukan CT perut, pemeriksaan laboratorium, dan beberapa kali endoskopi, hasilnya menunjukkan hipersplenisme sekunder karena HPNS. Pasien memiliki 13 endoskopi dan 2 EVL dalam 5 tahun. Meskipun pengobatan yang memadai, pasien mengalami perdarahan varises berulang dan tidak ada perbaikan fungsi darah. Pasien menjalani PSE di Pusat Jantung Terpadu RSUP Dr. Cipto Mangunkusumo, Jakarta, Indonesia, yang mana dilakukan melalui akses femoralis dengan embolus polyvinyl alcohol (PVA). Prosedur berjalan sukses, dan tidak ada komplikasi besar pada pasien. Dua puluh hari setelah pasien menjalani CT scan perut, tidak tampak abses, dan volume limpa berkurang 20\%. Hasil jangka panjang lebih dari setahun setelah prosedur dipresentasikan. PSE adalah alternatif semi-invasif yang aman, efektif, untuk splenektomi pada hipertensi portal non-sirosis karena mempertahankan massa limpa fungsional dan menghindari penyakit hati yang dipercepat pascaprosedur atau ensefalopati.

Kata kunci: hipertensi portal, embolisasi limpa, perdarahan varises

\section{INTRODUCTION}

Portal hypertension may be caused by varied underlying diseases and may have dangerous complications in patients. Port portal hypertension's pathophysiological features include obstructed and increased blood flow into the portal system, accompanied by the portal vein and collateral vessels with collateral circulation pressures. ${ }^{1}$ Splenomegaly, esophageal and fundal varices, and variceal bleeding due to portal hypertension may lead to thrombocytopenia, leukopenia, anemia. ${ }^{1-5}$ With an increase in mortality, the most severe complication of uncontrolled portal hypertension is acute variceal bleeding. ${ }^{1,2}$

Many procedures have been developed to treat portal hypertension and its complications. Portal hypertension complications have been traditionally managed with serial endoscopic variceal ligation (EVL) or invasive open surgical procedures such as orthotopic liver transplantation (OLT) or portosystemic shunting or splenectomy. ${ }^{6-9}$ Not every patient with portal hypertension may undergo a surgical procedure. Significant morbidity and mortality are related to surgical interventions because the patients frequently have significant co-morbidities. ${ }^{7}$ But, overwhelming post-splenectomy infection (OPSI) could arise from total splenectomy, along with other complications such as portal vein thrombosis. ${ }^{8,10}$ When standard therapy fails, a minimally invasive procedure called partial splenic embolization (PSE) may be an excellent alternative to prevent upper gastrointestinal bleeding among portal hypertension patients. ${ }^{7}$

In 1973, Maddison described PSE first to treat thrombocytopenia and variceal bleeding in cirrhotic patients. ${ }^{6,11}$ The procedure has been proposed to be a safe and effective alternative for managing portal hypertension. ${ }^{1,2,6,12}$ It is an original percutaneous interventional method that emerged as a promising alternative to surgery because it effectively reduces the size of splenic parenchyma through major branches of splenic artery embolization. ${ }^{5}$ The improvement of the technique has overcome several complications following the initial implementation of the procedure, such as splenic abscess, septicemia, and pneumonia. ${ }^{12}$ We reported a non-cirrhotic hypersplenism in a pediatric patient treated with PSE, with a good outcome in Dr Cipto Mangunkusumo General Hospital, Jakarta, Indonesia. The procedure has been widely used in Indonesia, but the publication of the reports is still scarce. Therefore, this case report aims to add more publications about the procedure and the outcome to guide surgeons and physicians in enriching their knowledge about treating patients with similar diseases.

\section{CASE ILLUSTRATION}

An eighteen-year-old male has had a splenomegaly history since he was 12 and had recurring hematemesis and melena. The hematology lab results before PSE showed pancytopenia (see Table 1).

The patient had 13 endoscopies and two esophageal variceal ligations in 5 years. The patient was hemodynamically stable with a heart rate of 95 tpm and blood pressure of $90 / 60 \mathrm{mmHg}$. In the physical examination, the looked pale, splenomegaly Schuffner VII. There was no lymphadenopathy. In the last endoscopy, six months before PSE, grade I/ III esophageal varices were found without bleeding 
stigmata, and there was also gastroduodenopathic portal hypertension duodenum solitary polyp. Therefore, the pancytopenia can be concluded to result from secondary hypersplenism due to non-cirrhotic portal hypertension. Even with adequate therapy, the patient did not experience significant improvement. His PSE pre-op (Day -5) lab result showed a normal serum liver function test and.

The patient underwent PSE at Integrated Cardiovascular Center in Cipto Mangunkusumo Hospital. It was performed through the femoral access with a PVA (polyvinyl alcohol) embolus. The patient had a recurrent fever seven days post-PSE (Day +7). The results of the complete blood count (CBC) can be seen in Table 1. No specific infection source was found, suggesting that the fever was probably caused by an inflammatory process in the embolized spleen.

The patient was subjected to another abdominal CT scan on Day +20 . It showed no abscess, and the spleen volume was reduced by $20 \%$ to $802.3 \mathrm{~mL}$ (see Figure 1). The spleen volume on the Abdomen CT examination two months prior was $4073.5 \mathrm{~mL}$ (see Figure 2). The patient received meropenem and tigecycline antibiotics.
The patient was followed up nine months post-treatment and was evaluated with esophagogastroduodenography (EGD). The EGD showed grade I esophageal varices and multiple duodenal polyps. After the EGD procedure, the patient was in stable condition, had no bleeding, and had a good appetite. Therefore, the patient was planned for another PSE. The hematology lab results of the patient after PSE can be seen in Table 1.

Table 1. The complete blood count (CBC) results of the patient before and after PSE

\begin{tabular}{clllll}
\hline No. & Time of examination & Hb & HCT & WBC & $\begin{array}{l}\text { PLT } \\
(\mathbf{x ~ 1 0 3 )}\end{array}$ \\
\hline 1 & Six months before PSE & 7.5 & 25.8 & 1620 & 17 \\
2 & Four months before PSE & 9.1 & 29.7 & 1500 & 19 \\
3 & One month before PSE & 8.3 & 25.9 & 2820 & 10 \\
4 & Day +1 & 9.8 & 29.8 & 5970 & 31 \\
5 & Day +7 & 8.2 & 26.4 & 10410 & 123 \\
6 & One month post-PSE & 8.9 & 27.3 & 6980 & 97 \\
7 & Three months post PSE & 11.1 & 34.2 & 3510 & 94 \\
8 & Seven months post PSE & 10.8 & 32.5 & 3190 & 47 \\
9 & 11 months post PSE & 10.2 & 32.2 & 2720 & 38 \\
\hline
\end{tabular}

Notes: Hb: Hemoglobin, HCT: Hematocrit, WBC: White blood cell count, PLT: platelet count, PSE: partial splenic embolization

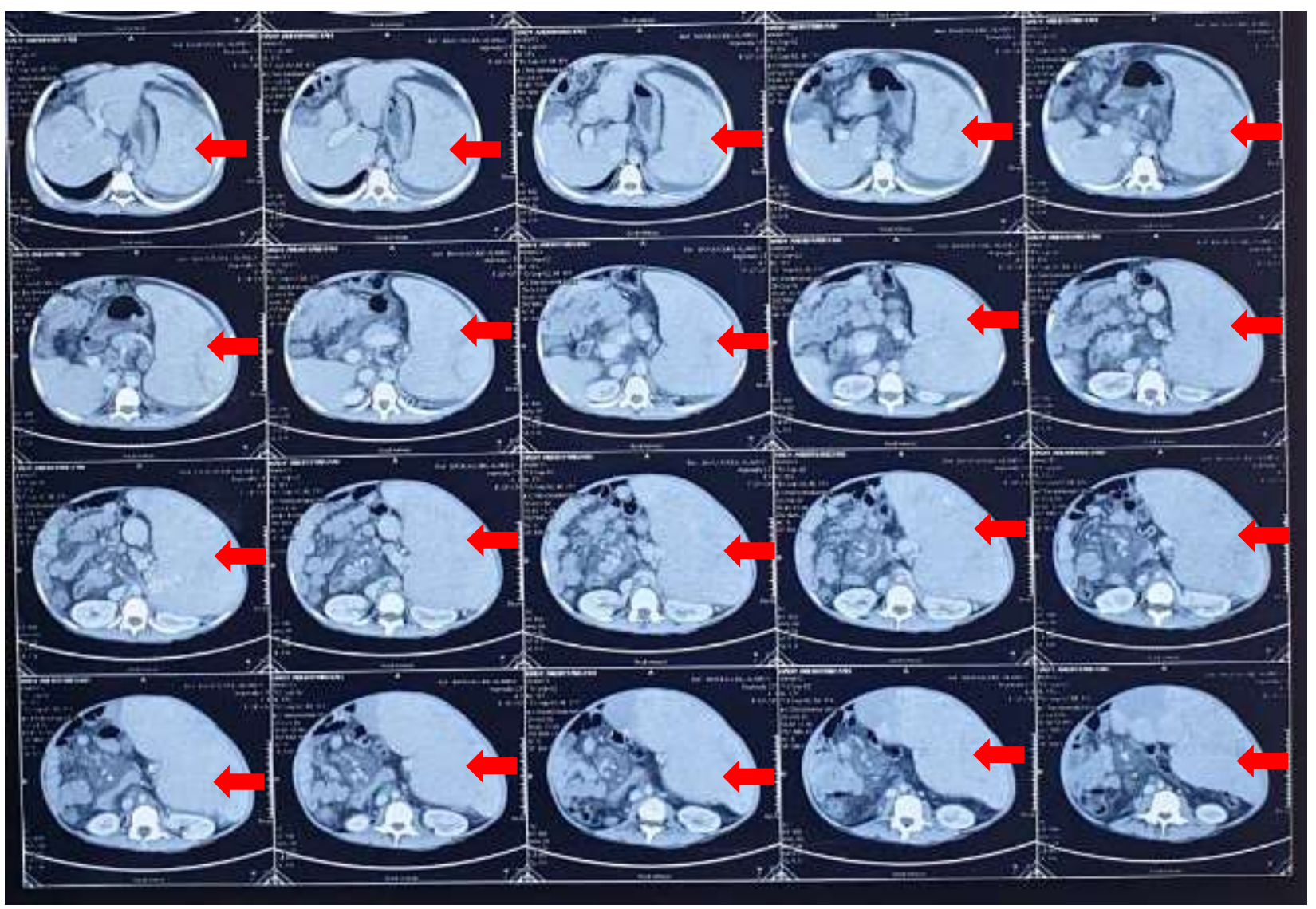

Figure 1. Abdomen CT Scan 6 months before PSE shows splenomegaly (shown by red arrows) with dilated splenic vein, demonstrating non-cirrhotic portal hypertension. The spleen volume is $4073.5 \mathrm{~mL}$ 


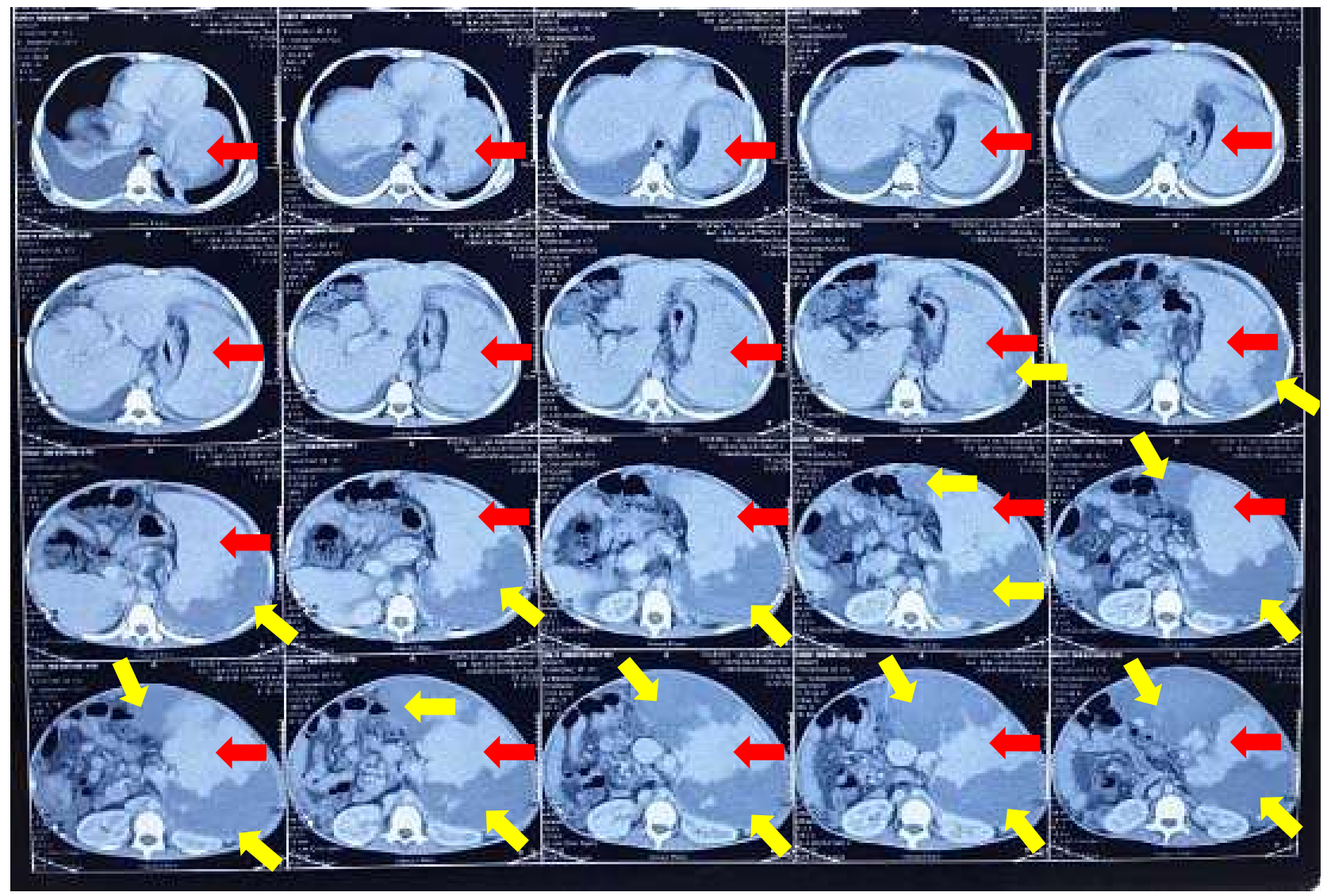

Figure 2. Abdomen CT Scan 20 days post PSE. There are wide hypodense (shown by yellow arrows) areas in the middle and inferior spleen (post embolization infarct area). The spleen volume absorbing contrast (indicated by red arrows) is about $802.3 \mathrm{~mL}$

\section{DISCUSSION}

Non-cirrhotic portal hypertension management mainly focuses on managing an acute episode of variceal bleeding accompanied by secondary prophylaxis. In $80-90 \%$ of patients, endoscopic ligation effectively controls esophageal varices acute bleeding and prevents rebleeding. Despite adequate treatment, the patient has slight improvement. It is similar to the result of a research of Khana et al, in which failure in controlling acute variceal bleeding may happen in $8-12 \%$ of endotherapy cases. ${ }^{13}$

Gastrointestinal haemorrhage complicating portal hypertension has become one of the main indications for splenectomy. ${ }^{13,14}$ Nonetheless, many case series recognized several risks associated with splenectomies, such as hemorrhagic complications or intraoperative blood loss. ${ }^{5,6,14}$ Arnold et al concluded there are some disadvantages of splenectomy. The disadvantages include a lack of validated response predictors. Furthermore, there is high 30-day mortality of surgical risk for laparoscopic splenectomy and higher for open splenectomy. Besides, there is an increased risk of vascular thrombosis and post-splenectomy infection. ${ }^{15}$

PSE has been considered as an alternative procedure to manage hypersplenism. The procedure was first described in 1973 by Maddison for treating thrombocytopenia and variceal bleeding in cirrhotic patients. ${ }^{15}$ The procedure disrupts the spleen's end arterioles to disrupt the arterial blood supply selectively, causing decreased spleen size and portal venous inflow through partial splenic infarction. Thus, increasing the circulating platelet count and also reducing the gastroesophageal varices sizes. ${ }^{6,10}$ Our patient's splenic volume decreased by about $80 \%$ in 20 days after the procedure. This outcome is consistent with a study by Gu et al in which the subjects splenic volume decreased significantly, peaking at two weeks after PSE. However, during the 4-year follow-up, the book then gradually increased. ${ }^{9}$

Our patient improved overall white blood cell (WBC) and platelet (PLT) count three days post-surgery. The increase in leukocyte counts may result from reducing the platelet pool due to reduced spleen volume. Indeed, due to decreased splenic sequestration and thrombopoietin restoration, the platelet count increased. ${ }^{4}$

The noticeable improvements post-PSE were an increase in PLT and WBC counts and haemoglobin. About a year post-PSE, the platelet count decreased, and the patient is planning for another PSE. The improvement of the hematologic indices is similar to 
other published articles. Splenectomy and PSE have been known to lead to splenomegaly regression, thus raising WBC and PLT counts. Jiao et al showed that postoperative WBC and PLT counts rose significantly in patients with a splenectomy or PSE $(\mathrm{p}<0.05) .{ }^{8} \mathrm{~A}$ study applied PSE in 26 critically ill adult patients with thrombocytopenia and bleeding esophageal varices. The outcome was a significant improvement in WBC and platelet counts, and haemoglobin values, along with a decrease in bleeding. ${ }^{3,6,7}$

However, some minor or significant complications arise from the PSE procedure. Minor complications were those with no clinical sequelae, which can be treated conservatively, such as abdominal fullness and postembolization syndrome. Complications requiring surgical intervention were categorized as significant and related to pleural effusion, splenic abscess, splenic rupture, gastrointestinal bleeding, and refractory ascites. ${ }^{9,10,16}$ Our patient had a fever seven days post-surgery, but it was effectively controlled with intravenous and oral analgesics. The embolization was done for $80 \%$ in our patients, but the complication was minimal.

After nine months of follow-up, the patient had thrombocytopenia without recurrent gastrointestinal bleeding. Our finding is consistent with Vittirio et al. Rather than the volume of spleen infarcted, thrombocytopenia recurrence appeared to be related to splenic regeneration. ${ }^{6}$ A shorter hypersplenism relapse is related to $<50 \%$ spleen embolization. It suggests that to be effective, PSE should cover a minimum of half of the spleen. ${ }^{5}$

PSE is a safe, effective, semi-invasive alternative to splenectomy in non-cirrhotic portal hypertension. It appears to avoid postprocedure accelerated liver disease or encephalopathy and preserve functional spleen mass. When the splenic volume and splenic venous return were reduced, portal flow and pressure were effectively reduced. Larger sample size and a longer follow-up would be helpful to further estimate PSE's clinical value for managing hypersplenism.

\section{ACKNOWLEDGMENTS}

We thanked Cipto Mangunkusumo General hospital for their hospitality and support for this research.

\section{REFERENCES}

1. Zhao Y, Guo L, Huang Q, Zhang R, Sun X, Zhao L, et al. Observation of immediate and mid-term effects of partial spleen embolization in reducing hepatic venous pressure gradient. Med (United States) 2019;98:1-6.
2. Muradia A, Waznan F, Jasirwanc C, Pratama D, Suhartono R. Pancytopenia and massive gastroesophageal bleeding due to hypersplenism treated with partial splenic embolization. J Indones Soc Vasc Endovasc Surg 2020;1:42-6.

3. Kim NH, Kim HJ, Cho YK, Hong HP, Kim BI. Longterm efficacy and Safety of partial splenic embolization in hepatocellular carcinoma patients with thrombocytopenia who underwent transarterial chemoembolization. J Korean Med Sci 2019;34:1-12.

4. Li LY, Chen HZ, Bao YC, Yu QS, Yang WM. Successful treatment of hypersplenism in Wilson's disease by partial splenic embolization. J Investig Surg 2018;31:75-81.

5. Ozturk O, Eldem G, Peynircioglu B, Kav T, Görmez A, Cil BE, et al. Outcomes of partial splenic embolization in patients with massive splenomegaly due to idiopathic portal hypertension. World J Gastroenterol 2016;22:9623-30.

6. Vittorio J, Orellana K, Martinez M, Ovchinsky N, Schlossberg $\mathrm{P}$, Griesemer A, et al. Partial splenic embolization is a safe and effective alternative in the management of portal hypertension in children. J Pediatr Gastroenterol Nutr 2019;68:793-8.

7. Buechter M, Kahraman A, Manka P, Gerken G, Dechêne A, Canbay A, et al. Partial spleen embolization reduces the risk of portal hypertension-induced upper gastrointestinal bleeding in patients not eligible for TIPS implantation. PLoS One 2017;12:1-11.

8. Jiao S, Chen H, Wang Y, Zhu J, Tan J, Gao J. Splenectomy versus partial splenic embolization for massive splenomegaly secondary to hepatitis b-related liver cirrhosis: A case-control study. Gastroenterol Res Pract 2016;2016:3471626.

9. Gu JJ, He XH, Li WT, Ji J, Peng WJ, Li GD, et al. Safety and efficacy of splenic artery coil embolization for hypersplenism in liver cirrhosis. Acta Radiol 2012;53:862-7.

10. Zheng L, Deng C, Li J, Wang L, You N, Wu K, et al. Treatment of hemangioma of the spleen by preoperative partial splenic embolization plus laparoscopic partial splenectomy. Med (United States) 2018;97:e0498.

11. Guan YS, Hu Y. Clinical application of partial splenic embolization. Sci World J 2014;2014.

12. Omer S, Zara O, Iacobescu C, Dina I. Partial splenic embolization for hypersplenism in cirrhotic patients. A case series. J Gastrointest Liver Dis 2014;23:215-8.

13. Khanna R, Sarin SK. Non-cirrhotic portal hypertension Diagnosis and management. J Hepatol 2014;60:421-41.

14. Zaitoun MMA, Basha MAA, Raafat A, Rushdy T, Mawla WA. Splenectomy for hypersplenism with or without preoperative splenic artery embolization. Eur Radiol Exp 2018;2:23.

15. Arnold DM, Zeller MP, Smith JW, Nazy I. Diseases of platelet number: immune thrombocytopenia, neonatal alloimmune thrombocytopenia, and posttransfusion purpura [serial online] [cited: August 17, 2021] $7^{\text {th }}$ ed. Hematology: Basic Principles and Practice. Elsevier Inc.; 2018.p. 1944-1954. Available from http://dx.doi.org/10.1016/B978-0-323-35762-3.00131-1.

16. Saddekni S, Moustafa AS, Tahoon HA, Setita M, AbdelAal AK. Treatment of hypersplenism by partial splenic embolization through gastric collaterals. J Radiol Case Rep 2016;10:28-35. 